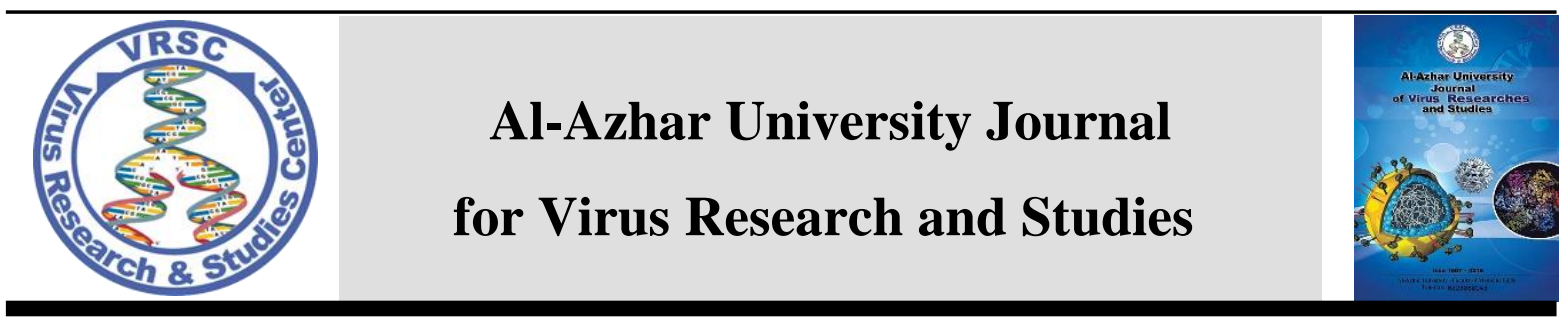

\title{
Influence of Iron Deficiency Anemia on Hemoglobin A1C
}

\author{
Laila M Aboughazala1, Fatma El Zahraa AE. Diab', Fatma M Khotb², Shimaa G. \\ Abdelhady ${ }^{1 *}$ \\ ${ }^{1}$ Clinical Pathology Department, Faculty of Medicine for Girls Al-Azhar University, Al- \\ Azhar University, Cairo, Egypt \\ ${ }^{2}$ Internal Medicine Department, Faculty of Medicine for Girls Al-Azhar University, Al- \\ Azhar University, Cairo, Egypt \\ *E-mail: sjmal724@gmail.com
}

\begin{abstract}
Glycated hemoglobin (HbA1c) is the predominant fraction of hemoglobin A1(HbA1), and it constitutes $5 \%$ of the total $\mathrm{Hg}$ in normal adults and up to $15 \%$ in patients with diabetes mellitus (DM). It is used as a clinical indicator of the blood sugar level of an individual during the previous three months. There are several medical conditions that affect and lead to falsely higher or lower values of HbA1c unrelated to diabetes including hemolytic anemias, acute blood loss, iron deficiency (ID), alcoholism, pregnancy, chronic kidney disease and hemoglobinopathies. Several studies reported that reduced iron stores have a link with increased level of $\mathrm{HbA} 1 \mathrm{c}$ in the blood leading to false high values of $\mathrm{HbA} 1 \mathrm{c} .40$ patients with iron deficiency anemia (IDA), their ages ranged from (20 to 50) years old, and 35 cases apparently healthy individuals, their ages were matched with patients were included into the study. Complete blood count (CBC), fasting blood glucose (FBG), serum ferritin, kidney function tests (KFTs), and HbA1c levels were done for all samples. Hemoglobin $(\mathrm{Hb})$, mean corpuscular volume (MCV), mean corpuscular hemoglobin $(\mathrm{MCH})$, hematocrit (HCT), and ferritin were lower in IDA patients than control group, red distribution width (RDW), and platelet (PLT) were increased in IDA patients than control group, patients with IDA had higher HbA1c levels when compared with control group, and there were negative correlations between $\mathrm{HbA} 1 \mathrm{c}$ with $\mathrm{Hb}, \mathrm{MCV}, \mathrm{MCH}$, and ferritin in studied group. Our study proved that patients with IDA had higher values of HbA1c than healthy group, so correction of IDA by iron supplementation should be done before using $\mathrm{HbA} 1 \mathrm{c}$ in the diagnosis and monitoring of diabetes.
\end{abstract}

Keywords: IDA, HbA1c, non-diabetic IDA patients.

\section{Introduction}

Iron deficiency anemia is one of the most common types of nutritional anemia in the worldwide and considered a major public health problem in developing countries [1]. Iron deficiency anemia affects more than 2 billion peoples worldwide, the prevalence of ID is approximately $40 \%$ in preschool children, $38 \%$ in pregnant women, and $30 \%$ in menstruating girls and women [2]. Ferritin is the storage form of iron, and it reflects the iron status accurately [3]. Since 2010, there has been a change in 
using $\mathrm{HbA} 1 \mathrm{c}$ for more than just glycemic control, and it is now accepted for the diagnosis of diabetes. The Diabetes Control and Complications Trial (DCCT) and the United Kingdom Prospective Diabetes Study (UKPDS) are two major clinical trials that show a clear link between metabolic control (as measured by $\mathrm{HbA1c}$ ) and the risk of chronic diabetes complications. Worldwide diabetic centers recommend and use specific $\mathrm{HbA} 1 \mathrm{c}$ targets in terms of DCCT/UKPDS HbA1c [4].

Glycated hemoglobin is formed by the nonenzymatic reaction between glucose and the $\mathrm{N}$-terminal end of the $\beta$-chain [5].

Glycated hemoglobin is the predominant fraction of $\mathrm{HbA} 1$ and it constitutes $5 \%$ of the total $\mathrm{Hg}$ in normal adults and up to $15 \%$ in patients with DM [6].

Hemoglobin A to HbA1c conversion takes place during the entire life span of the red blood cells (RBCs), and the rate of this reaction is faster in diabetics because of the high glucose concentration, resulting in a higher concentration of $\mathrm{HbA1c}$ [6].

Clinically there are three major factors on which HbA1c levels depend:

1- HbA1c in reticulocytes when released from the BM.

2- Concentration of glucose to which $\mathrm{Hb}$ is exposed.

3- The mean age of RBCs in the circulation [7].

There are several medical conditions that affect and lead to falsely higher or lower values of $\mathrm{HbA1c}$ unrelated to diabetes including hemolytic anemias, acute blood loss, ID, alcoholism, pregnancy, chronic kidney disease and hemoglobinopathies [6].

\section{Materials and Methods}

This case control study was carried out on 40 patients with IDA selected from AlZahraa University Hospital in the period from January 2020 to June 2020, their ages ranged from (20 to 50) years old. 35 cases apparently healthy individuals were selected as a control group and their ages were matched with patients.

\subsection{Inclusion criteria:}

1. Presence of anemia defined as $\mathrm{Hb}<$ $13.0 \mathrm{~g} / \mathrm{dL}$ in males and in females < $12.0 \mathrm{~g} / \mathrm{Dl}$.

2. Serum ferritin $<13 \mathrm{ng} / \mathrm{ml}$.

3. Normal FBG.

4. Normal blood urea and serum creatinine (create).

5. Age from 20 to 50 years old.

\subsection{Exclusion criteria:}

Patient with a history of acute blood loss, hemolytic anemia, hemoglobinopathies, kidney disease, pregnancy, and DM.

Full history including age, rising of the blood sugar and serum create, acute blood loss, and pregnancy was taken, and full clinical examination was done for all subjects.

$5 \mathrm{ml}$ of venous blood were collected in the morning after the subject had fasted for $8 \mathrm{~h}$ and divided in to:

a. $2 \mathrm{ml}$ of blood anticoagulated with EDTA for CBC and HbA1c.

b. $3 \mathrm{ml}$ of blood were left to clot and centrifuged (for 15 minutes at $1000 \mathrm{xg}$ ) and sera were separated for fasting blood sugar, KFT, and ferritin.

CBC was performed by fully automated cell counter Sysmex KX 21N (Germany) kits of Siemens (Germany), fasting blood sugar and KFT were performed by fully automated chemistry analyzer cobas c 311(Germany), serum ferritin was performed by fully automated Varioskan LUX multimode reader - Thermo Fisher (Germany), and HbA1c by Capillary 2 Flex - Piercing Technique (C2FP) (SebiaFrance). 
3. Results

Table 1. Comparison between studied groups as regard age, sex, CBC, FBS, kidney functions, serum ferritin \& $\mathrm{HbA} 1 \mathrm{C}$.

\begin{tabular}{|c|c|c|c|c|c|}
\hline & & $\begin{array}{l}\text { Patients } \\
(\mathrm{N}=40)\end{array}$ & $\begin{array}{l}\text { Control } \\
(\mathbf{N}=35)\end{array}$ & Stat. test & P-value \\
\hline $\begin{array}{c}\text { Age } \\
\text { (years) }\end{array}$ & $\begin{array}{c}\text { Mean } \pm \text { SD } \\
\text { Median }\end{array}$ & $\begin{array}{c}32.4 \pm 9.9 \\
32.5\end{array}$ & $\begin{array}{c}28.7 \pm 5.4 \\
28 \\
\end{array}$ & $\mathrm{MW}=581.5$ & $0.207 \mathrm{NS}$ \\
\hline Sex & $\begin{array}{c}\text { Male } \\
\text { Female }\end{array}$ & $\begin{array}{cr}3 & 7.5 \% \\
37 & 92.5 \%\end{array}$ & $\begin{array}{ll}30 & 85.7 \% \\
5 & 14.3 \%\end{array}$ & $X^{2}=46.3$ & $<0.001 \mathrm{HS}$ \\
\hline $\begin{array}{l}\text { WBCs } \\
\left(\mathbf{x} 10^{3} / \mu l\right)\end{array}$ & $\begin{array}{c}\text { Mean } \pm \text { SD } \\
\text { Median }\end{array}$ & $\begin{array}{c}7.5 \pm 2.3 \\
7.9\end{array}$ & $\begin{array}{c}6.6 \pm 1.7 \\
6.3\end{array}$ & $\mathrm{MW}=558.5$ & $0.132 \mathrm{NS}$ \\
\hline $\mathrm{Hb}(\mathrm{g} / \mathrm{dl})$ & $\begin{array}{c}\text { Mean } \pm \text { SD } \\
\text { Median }\end{array}$ & $\begin{array}{c}9.8 \pm 1.02 \\
10\end{array}$ & $\begin{array}{c}13.7 \pm 0.8 \\
13.6\end{array}$ & $\mathbf{M W}=\mathbf{0 . 0}$ & $<0.001 \mathrm{HS}$ \\
\hline $\begin{array}{c}\text { MCV } \\
\text { (fl/cell) }\end{array}$ & $\begin{array}{c}\text { Mean } \pm \text { SD } \\
\text { Median }\end{array}$ & $\begin{array}{c}71.7 \pm 5.6 \\
72.9\end{array}$ & $\begin{array}{c}83.2 \pm 4.6 \\
82.5\end{array}$ & $M W=53.5$ & $<0.001 \mathrm{HS}$ \\
\hline $\begin{array}{c}\text { MCH } \\
\text { (mg/dl) }\end{array}$ & $\begin{array}{c}\text { Mean } \pm \text { SD } \\
\text { Median }\end{array}$ & $\begin{array}{c}21.5 \pm 2.4 \\
21.7\end{array}$ & $\begin{array}{c}28.8 \pm 1.3 \\
28.3\end{array}$ & $M W=13$ & $<0.001 \mathrm{HS}$ \\
\hline HCT (\%) & $\begin{array}{c}\text { Mean } \pm \text { SD } \\
\text { Median }\end{array}$ & $\begin{array}{c}33 \pm 2.7 \\
33.4\end{array}$ & $\begin{array}{c}37.9 \pm 4.2 \\
38\end{array}$ & $M W=238.5$ & $<0.001 \mathrm{HS}$ \\
\hline $\begin{array}{c}\text { RDW } \\
(\%)\end{array}$ & $\begin{array}{c}\text { Mean } \pm \text { SD } \\
\text { Median }\end{array}$ & $\begin{array}{c}16.7 \pm 2.2 \\
16.6\end{array}$ & $\begin{array}{c}11.8 \pm 1.4 \\
11.5\end{array}$ & $M W=46.5$ & $<0.001 \mathrm{HS}$ \\
\hline $\begin{array}{c}\text { PLT } \\
\left(\mathbf{x 1 0}^{3} / \mu \mathrm{l}\right)\end{array}$ & $\begin{array}{c}\text { Mean } \pm \text { SD } \\
\text { Median }\end{array}$ & $\begin{array}{c}342.3 \pm 93.1 \\
324.5\end{array}$ & $\begin{array}{c}258.3 \pm 59.6 \\
250\end{array}$ & $\mathrm{MW}=\mathbf{3 0 5}$ & $<0.001 \mathrm{HS}$ \\
\hline $\begin{array}{c}\text { FBS } \\
(\mathrm{mg} / \mathrm{dl})\end{array}$ & $\begin{array}{c}\text { Mean } \pm \text { SD } \\
\text { Median }\end{array}$ & $\begin{array}{c}89.5 \pm 7.4 \\
90\end{array}$ & $\begin{array}{c}89.7 \pm 5.9 \\
90\end{array}$ & $\mathrm{MW}=694.5$ & $0.953 \mathrm{NS}$ \\
\hline $\begin{array}{c}\text { Urea } \\
\text { (mg/dl) }\end{array}$ & $\begin{array}{c}\text { Mean } \pm \text { SD } \\
\text { Median }\end{array}$ & $\begin{array}{c}26.7 \pm 10.9 \\
24\end{array}$ & $\begin{array}{c}23.4 \pm 12.9 \\
18\end{array}$ & $\mathrm{MW}=529.5$ & $0.07 \mathrm{NS}$ \\
\hline $\begin{array}{l}\text { Creat } \\
\text { (mg/dl) }\end{array}$ & $\begin{array}{c}\text { Mean } \pm \text { SD } \\
\text { Median }\end{array}$ & $\begin{array}{c}0.78 \pm 0.23 \\
0.75\end{array}$ & $\begin{array}{c}0.75 \pm 0.16 \\
0.8\end{array}$ & $\mathrm{MW}=673.5$ & $0.776 \mathrm{NS}$ \\
\hline $\begin{array}{c}\text { Ferritin } \\
(\mu \mathrm{g} / \mathrm{L})\end{array}$ & $\begin{array}{c}\text { Mean } \pm \text { SD } \\
\text { Median }\end{array}$ & $\begin{array}{c}6.4 \pm \frac{3.1}{6} \\
\text { a }\end{array}$ & $\begin{array}{c}108.9 \pm 72.8 \\
89\end{array}$ & $\mathbf{M W}=\mathbf{0 . 0}$ & $<0.001 \mathrm{HS}$ \\
\hline $\begin{array}{l}\text { HbA1C } \\
(\%)\end{array}$ & $\begin{array}{l}\text { Mean } \pm \text { SD } \\
\text { Median }\end{array}$ & $\begin{array}{c}5.5 \pm 0.5 \\
5.5\end{array}$ & $\begin{array}{c}4.6 \pm 0.5 \\
4.8\end{array}$ & $M W=116.5$ & $<0.001 \mathrm{HS}$ \\
\hline
\end{tabular}

MW: Mann-Whitney Test. $\mathrm{X}^{2}$ : Chi-square test.
HS: p-value $<0.001$ is considered highly significant. NS: $p$-value $>0.05$ is considered non-significant. 
- No statistically significant difference (p-value $>\mathbf{0 . 0 5}$ ) between studied groups as regard age. The mean age in patients' group was $32.4 \pm 9.9$ years (median $=32.5$ years) while it was $28.7 \pm$ 5.4 years $($ median $=28$ years $)$ in control group.

- Highly statistically significant difference (p-value $<\mathbf{0 . 0 0 1 )}$ between studied groups as regard sex. There were 3 males $(7.5 \%) \&$ 37 females $(92.5 \%)$ in patients' group while there were 30 males $(85.7 \%) \& 5$ females $(14.3 \%)$ in control group.

- No statistically significant difference (p-value $>\mathbf{0 . 0 5}$ ) between studied groups as regard WBCs. The mean WBCs in patients' group was $7.5 \pm 2.3$ $\mathrm{x} 10^{3} / \mu \mathrm{l}\left(\right.$ median $\left.=7.9 \mathrm{x} 10^{3} / \mu \mathrm{l}\right)$ while it was $6.6 \pm 1.7 \times 10^{3} / \mu 1$ $\left(\right.$ median $\left.=6.3 \times 10^{3} / \mu 1\right)$ in control group.

- Highly statistically significant difference (p-value $<\mathbf{0 . 0 0 1}$ ) between studied groups as regard $\mathrm{Hb}, \mathrm{MCV}, \mathrm{MCH}, \mathrm{HCT}, \mathrm{RDW} \&$ PLT as follows:

$\checkmark$ The mean $\mathrm{Hb}$ in patients' group was $9.8 \pm 1.02 \mathrm{~g} / \mathrm{dl}$ $($ median $=10 \mathrm{~g} / \mathrm{dl})$ while it was $13.7 \pm 0.8 \mathrm{~g} / \mathrm{dl}$ (median $=13.6 \mathrm{~g} / \mathrm{dl}$ ) in control group.

$\checkmark$ The mean MCV in patients' group was $71.7 \pm 5.6 \mathrm{fl} /$ cell (median $=72.9 \mathrm{fl} /$ cell $)$ while it was $83.2 \pm 4.6$ $\mathrm{fl} /$ cell (median $=82.5$ $\mathrm{fl} /$ cell) in control group.

$\checkmark$ The mean MCH in patients' group was $21.5 \pm 2.4 \mathrm{mg} / \mathrm{dl}$ (median $=21.7 \mathrm{mg} / \mathrm{dl})$ while it was $28.8 \pm 1.3$ $\mathrm{mg} / \mathrm{dl}$ (median $=28.3$ $\mathrm{mg} / \mathrm{dl}$ ) in control group.

$\checkmark$ The mean HCT in patients' group was $33 \pm 2.7 \%$
$($ median $=33.4 \%)$ while it was $37.9 \pm 4.2 \%$ (median $=$ $38 \%$ ) in control group.

$\checkmark$ The mean RDW in patients' group was $16.7 \pm 2.2 \%$ $($ median $=16.6 \%)$ while it was $11.8 \pm 1.4 \%$ (median $=$ $11.5 \%$ ) in control group.

$\checkmark$ The mean PLT in patients' group was $342.3 \pm 93.1$ $\mathrm{x} 10^{3} / \mu 1$ (median $=324.5$ $\left.\mathrm{x} 10^{3} / \mu \mathrm{l}\right)$ while it was 258.3 $\pm 59.6 \times 10^{3} / \mu 1$ (median $=$ $250 \times 10^{3} / \mu 1$ ) in control group.

- No statistically significant difference (p-value $>\mathbf{0 . 0 5})$ between studied groups as regard FBS, blood urea \& serum Creat. The mean FBS in patients' group was $89.5 \pm 7.4 \mathrm{mg} / \mathrm{dl}$ (median $=90$ $\mathrm{mg} / \mathrm{dl})$ while it was $89.7 \pm 5.9$ $\mathrm{mg} / \mathrm{dl}$ (median $=90 \mathrm{mg} / \mathrm{dl}$ ) in control group. The mean blood urea in patients' group was $26.7 \pm 10.9$ $\mathrm{mg} / \mathrm{dl}$ (median $=24 \mathrm{mg} / \mathrm{dl}$ ) while it was $23.4 \pm 12.9 \mathrm{mg} / \mathrm{dl}$ (median $=18$ $\mathrm{mg} / \mathrm{dl}$ ) in control group. The mean serum Create in patients' group was $0.78 \pm 0.23 \mathrm{mg} / \mathrm{dl}$ (median = $0.75 \mathrm{mg} / \mathrm{dl}$ ) while it was $0.75 \pm$ $0.16 \mathrm{mg} / \mathrm{dl}$ (median $=0.8 \mathrm{mg} / \mathrm{dl})$ in control group.

- Highly statistically significant difference (p-value $<\mathbf{0 . 0 0 1 )}$ between studied groups as regards serum ferritin \& HbA1C. The mean serum ferritin in patients' group was $6.4 \pm 3.1 \mu \mathrm{g} / \mathrm{L}$ (median $=6$ $\mu \mathrm{g} / \mathrm{L})$ while it was $108.9 \pm 72.8$ $\mu \mathrm{g} / \mathrm{L}$ (median $=89 \mu \mathrm{g} / \mathrm{L}$ ) in control group. The mean $\mathrm{HbA1C}$ in patients' group was $5.5 \pm 0.5 \%$ (median $=5.5 \%)$ while it was $4.6 \pm$ $0.5 \%$ (median $=4.8 \%)$ in control group. 


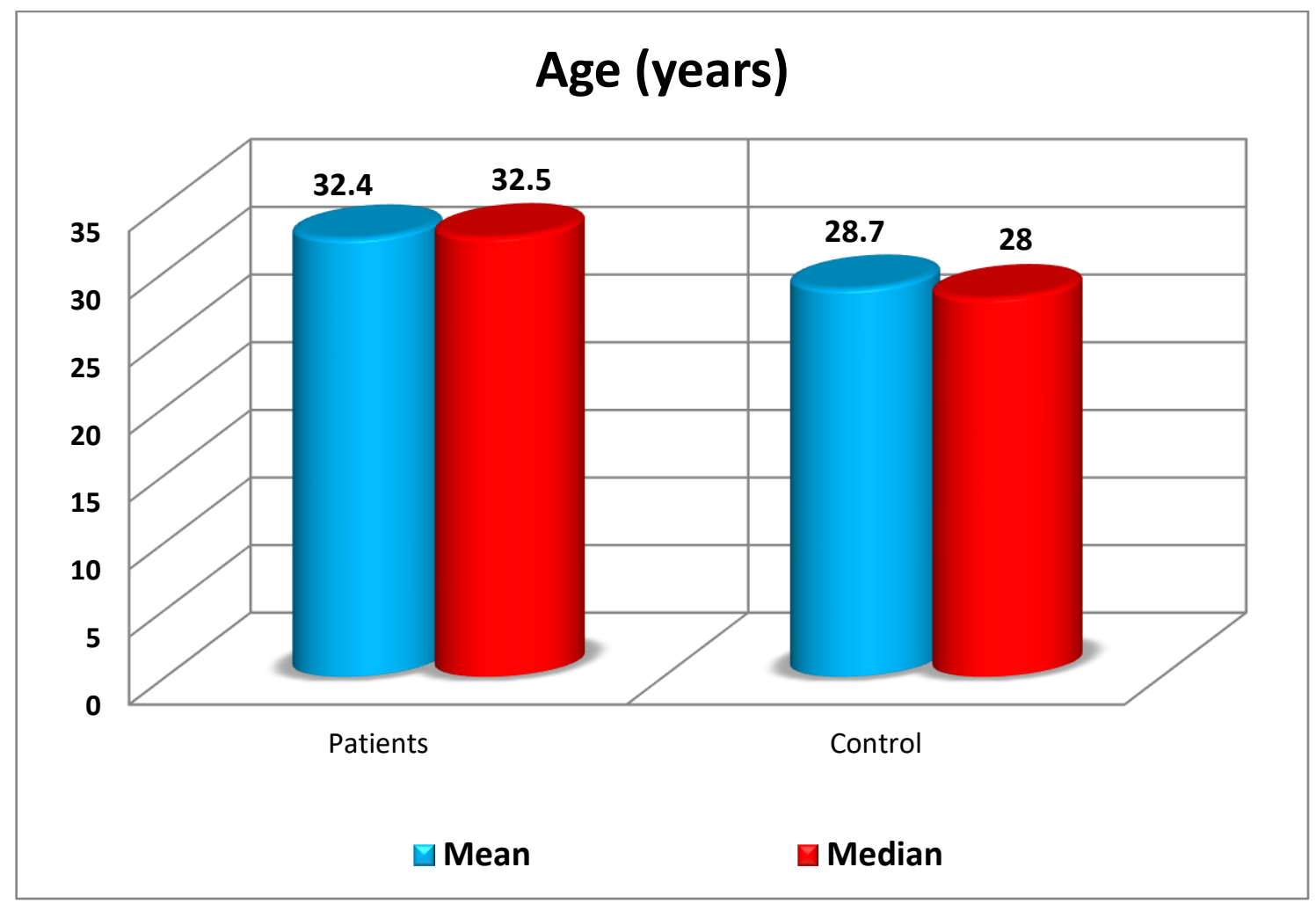

Figure (1): Comparison between studied groups as regard age.

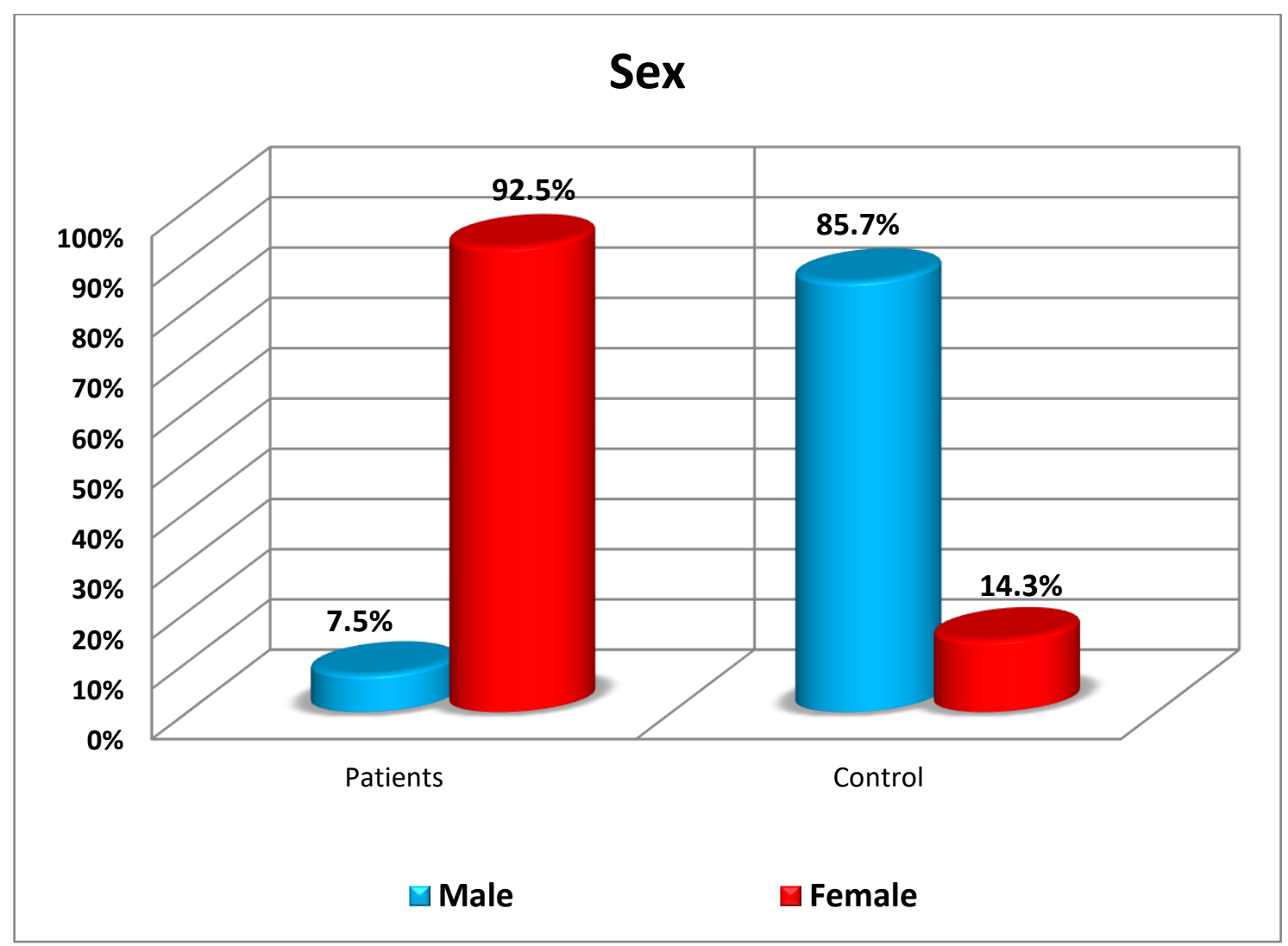

Figure (2): Comparison between studied groups as regard sex. 


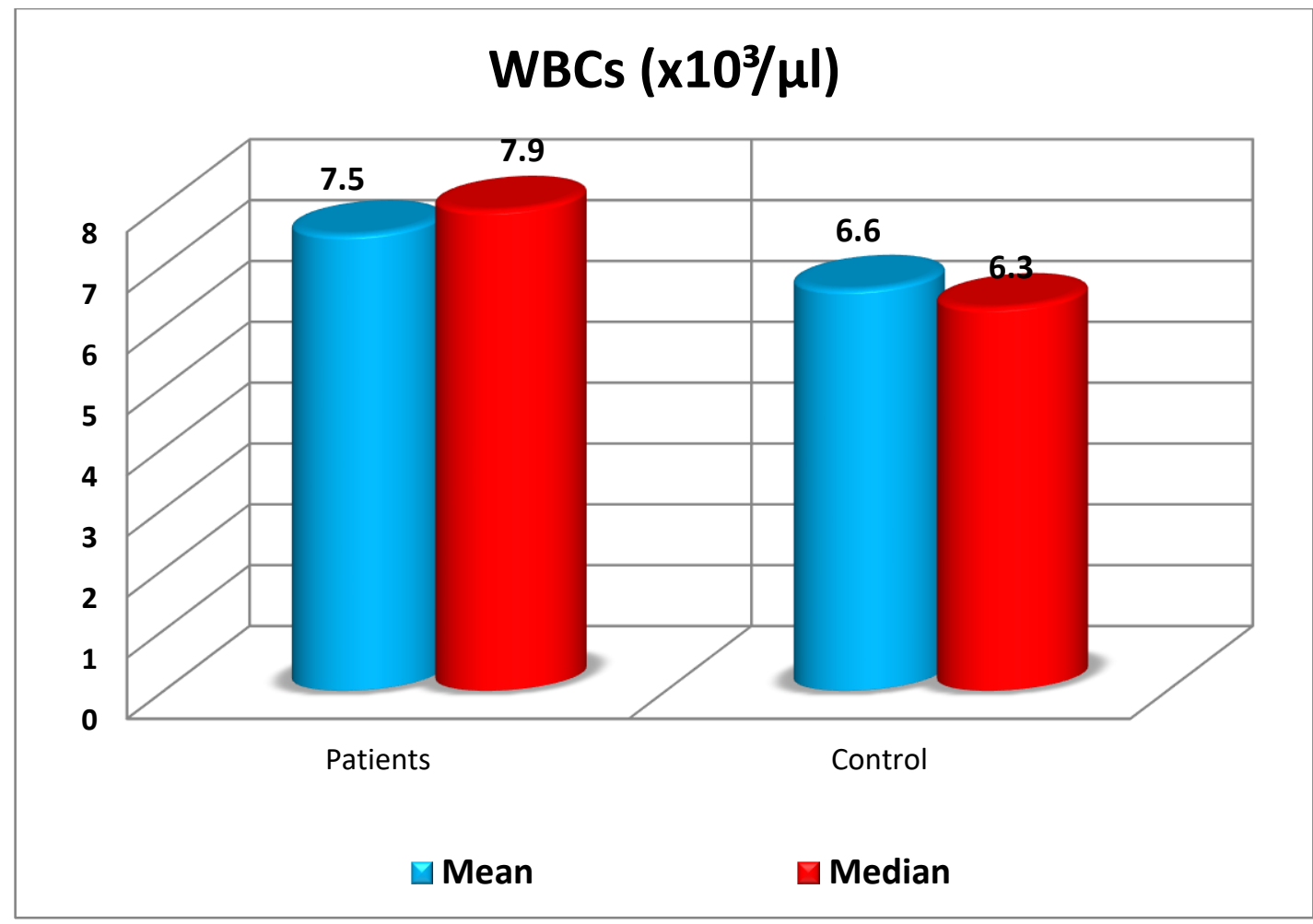

Figure (3): Comparison between studied groups as regard WBCs.

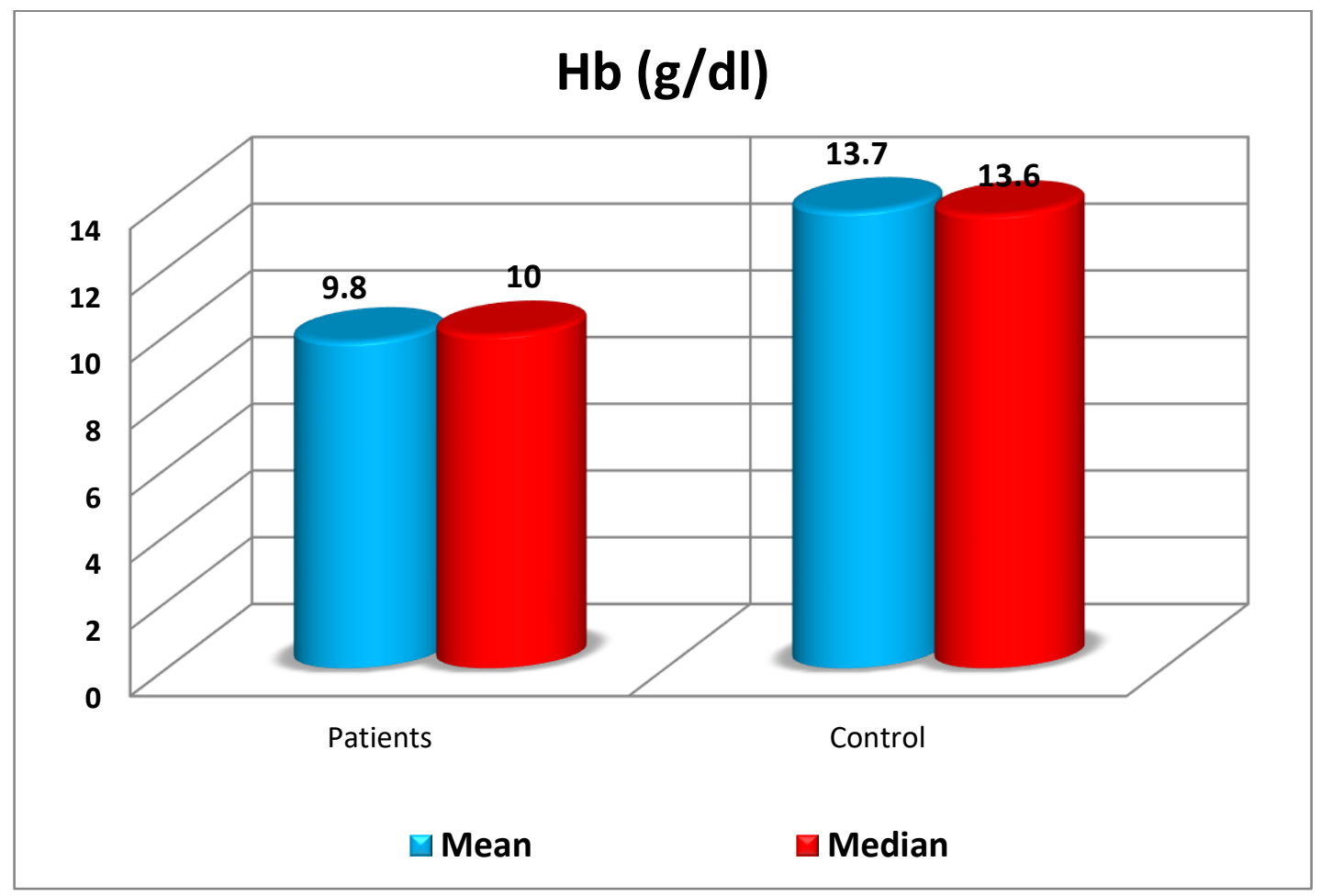

Figure (4): Comparison between studied groups as regard $\mathrm{Hb}$. 


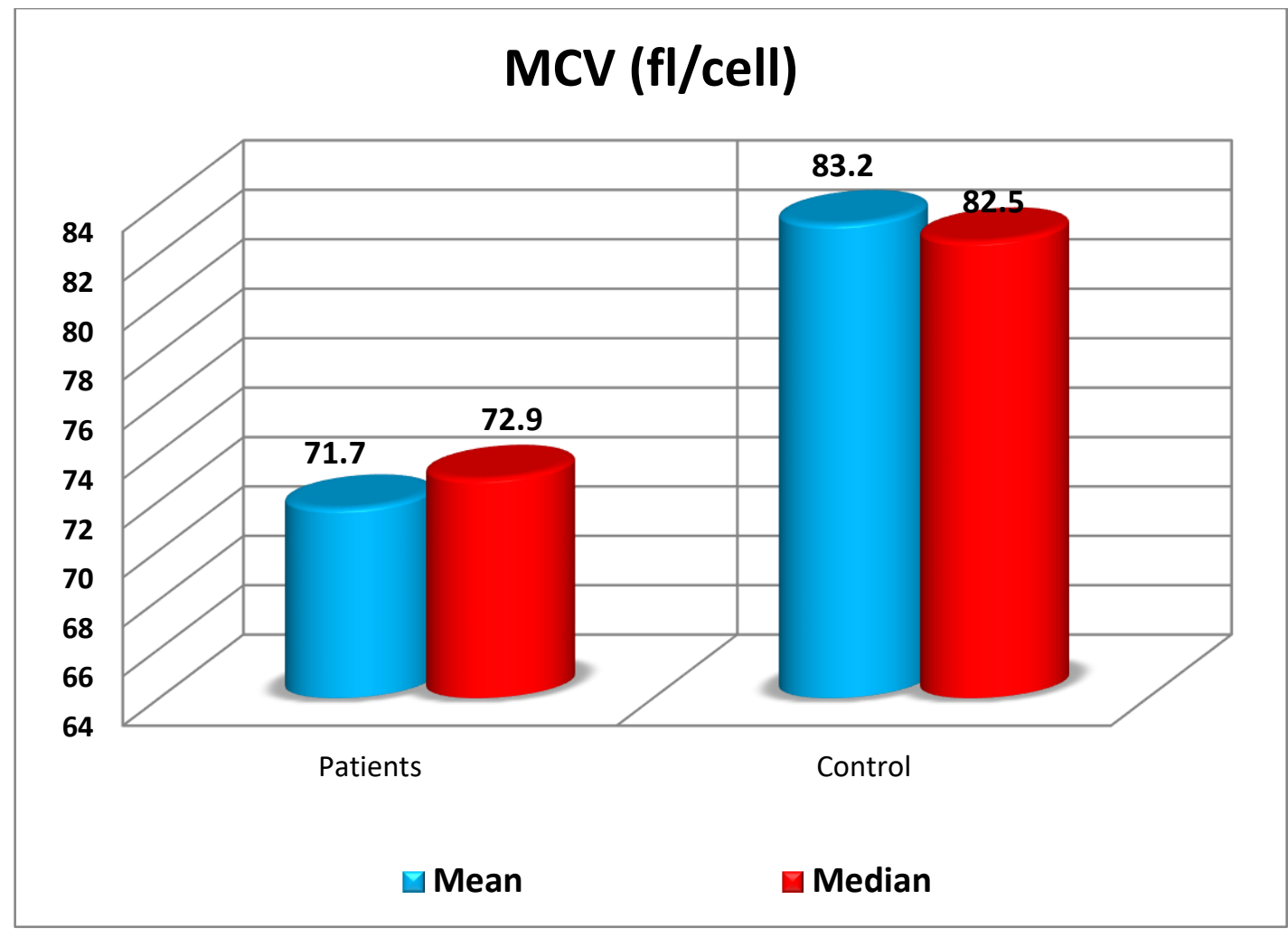

Figure (5): Comparison between studied groups as regard MCV.

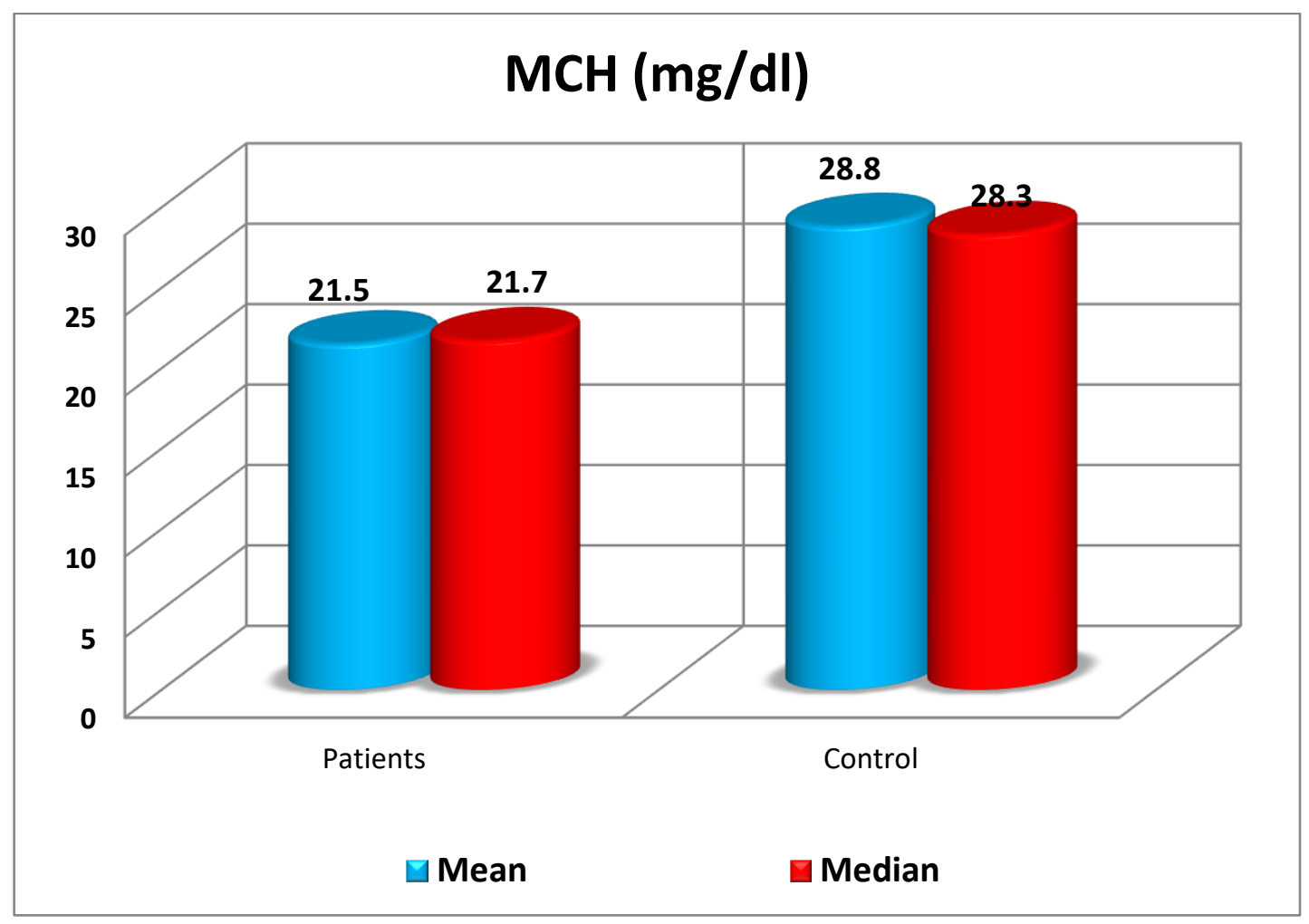

Figure (6): Comparison between studied groups as regard $\mathrm{MCH}$. 


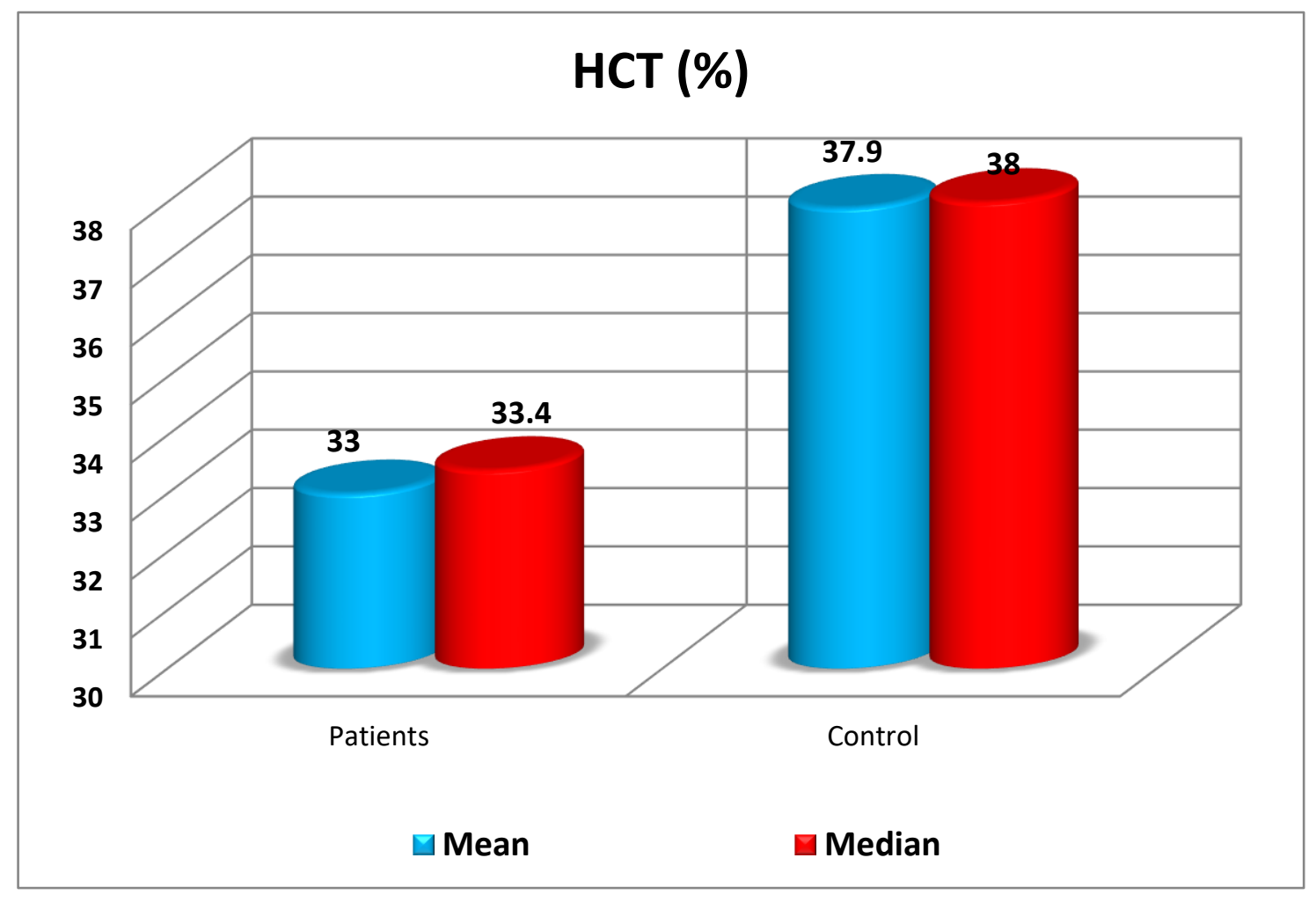

Figure (7): Comparison between studied groups as regard HCT.

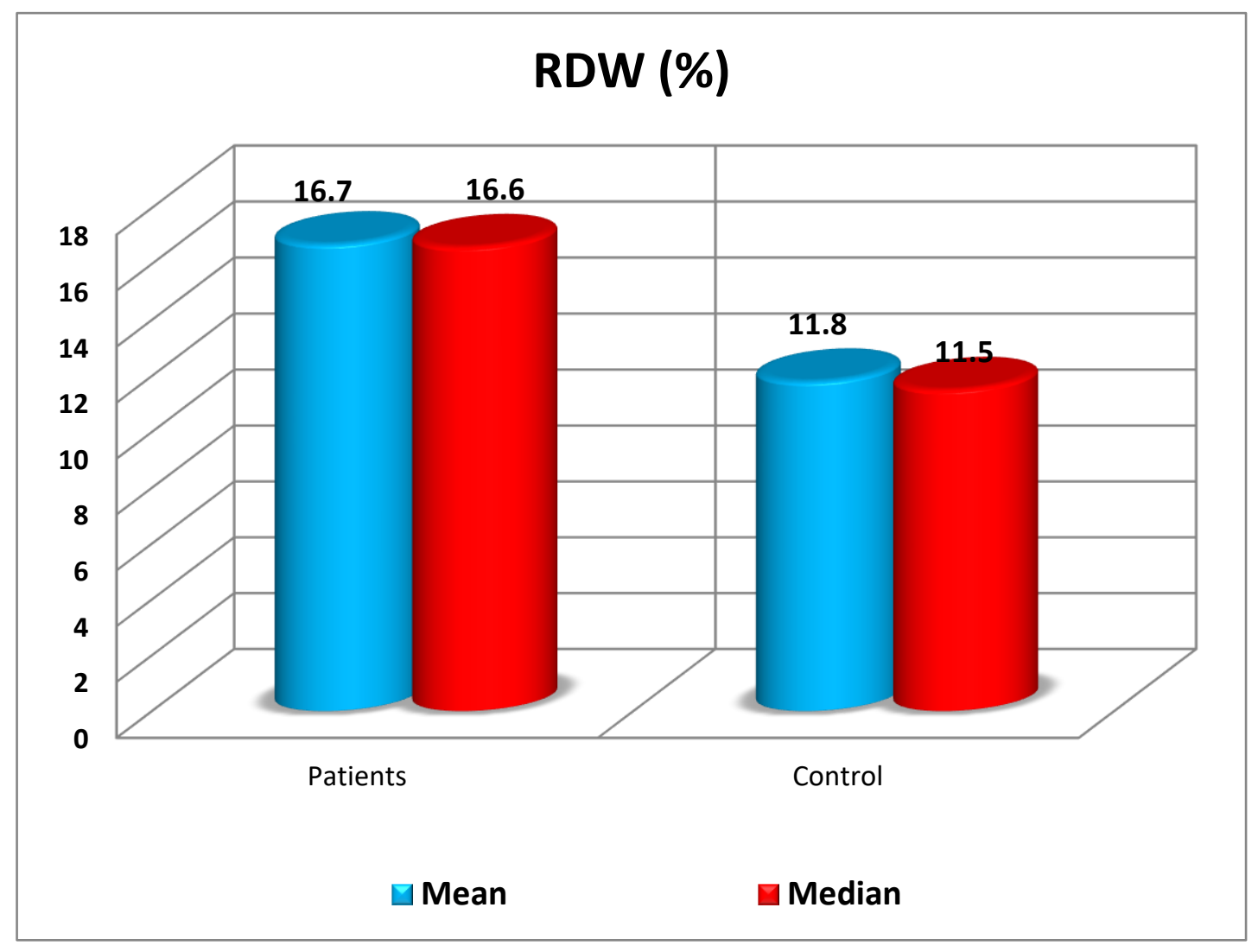

Figure (8): Comparison between studied groups as regard RDW. 


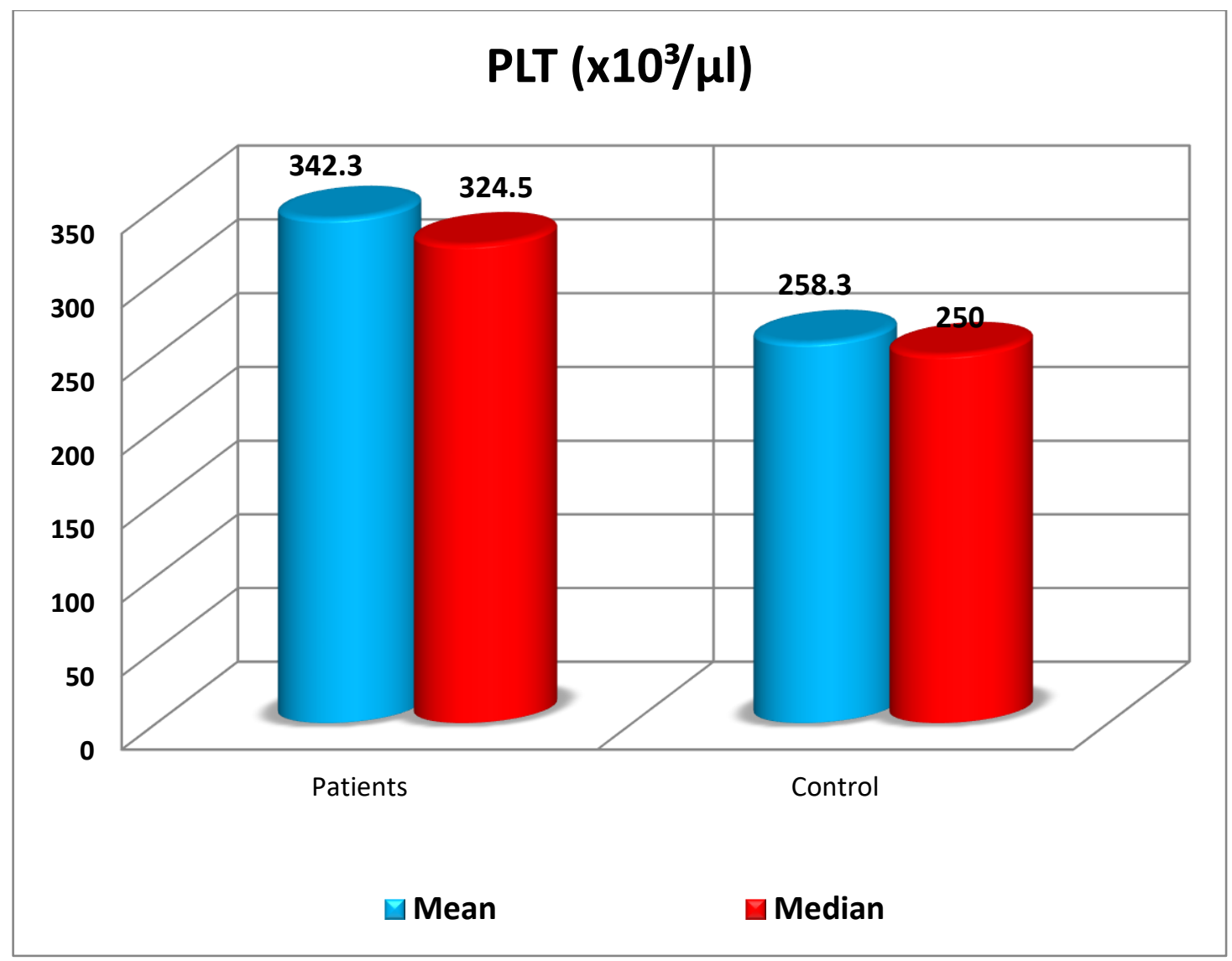

Figure (9): Comparison between studied groups as regard PLT.

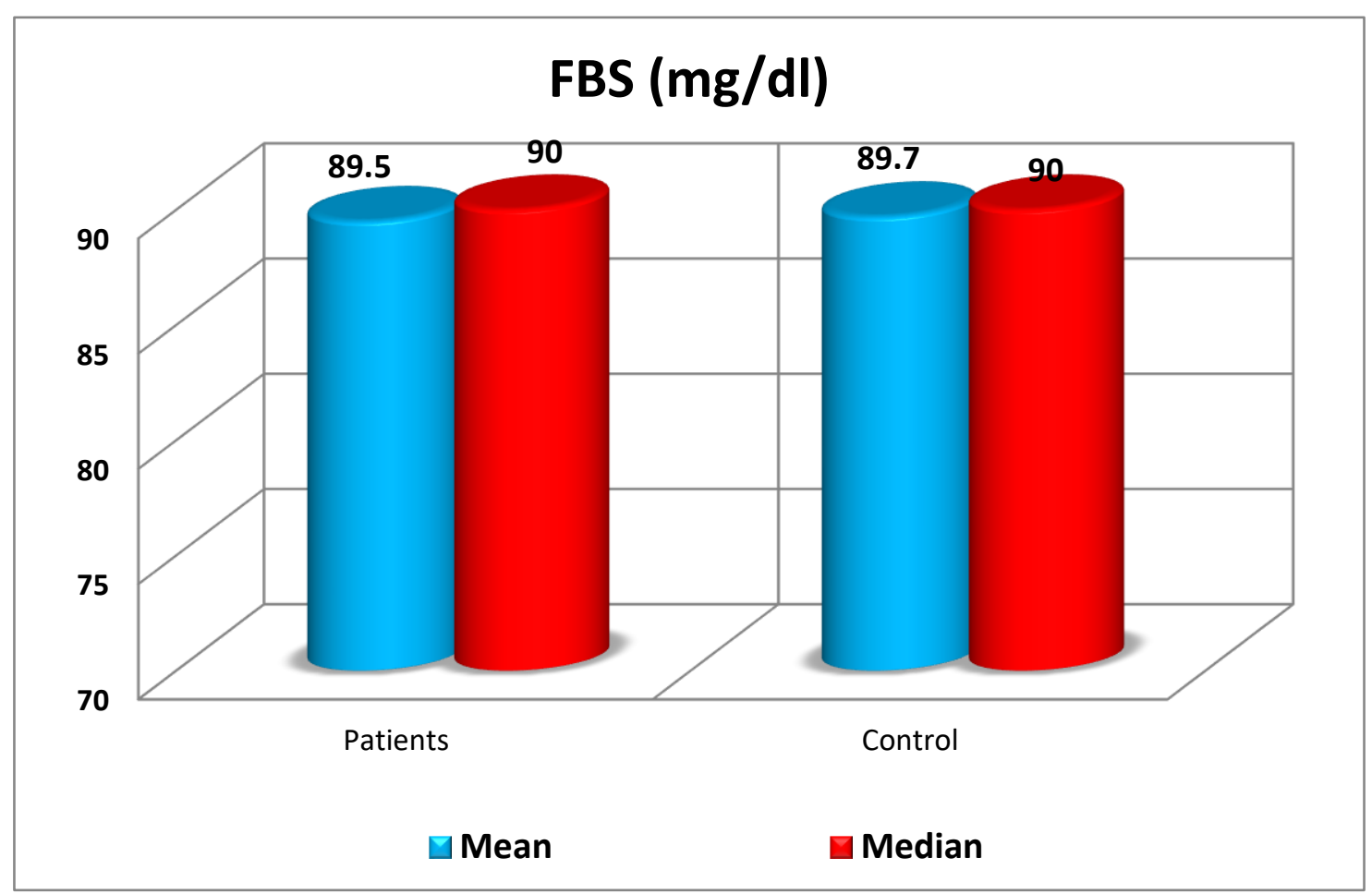

Figure (10): Comparison between studied groups as regard FBS 


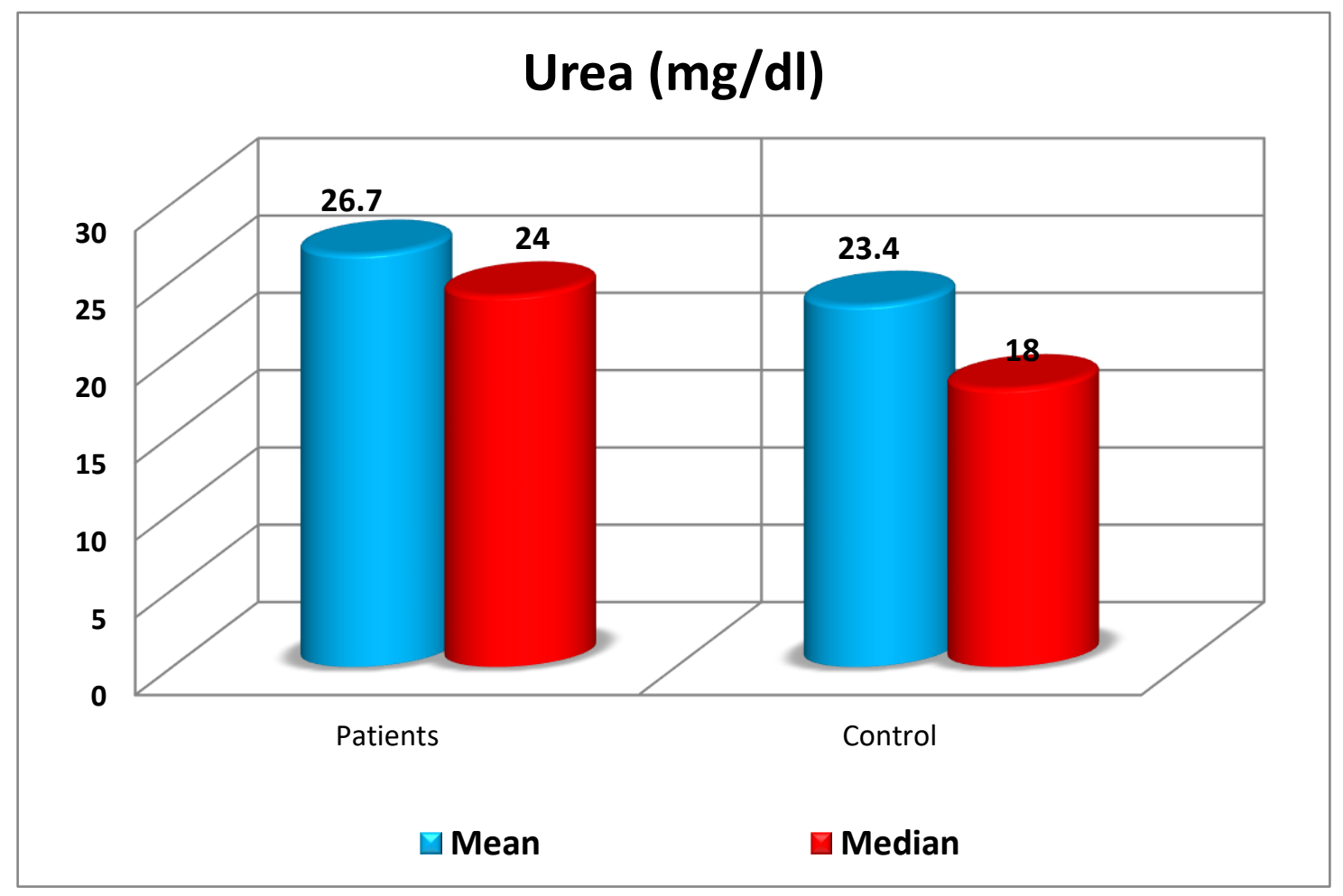

Figure (11): Comparison between studied groups as regard blood urea.

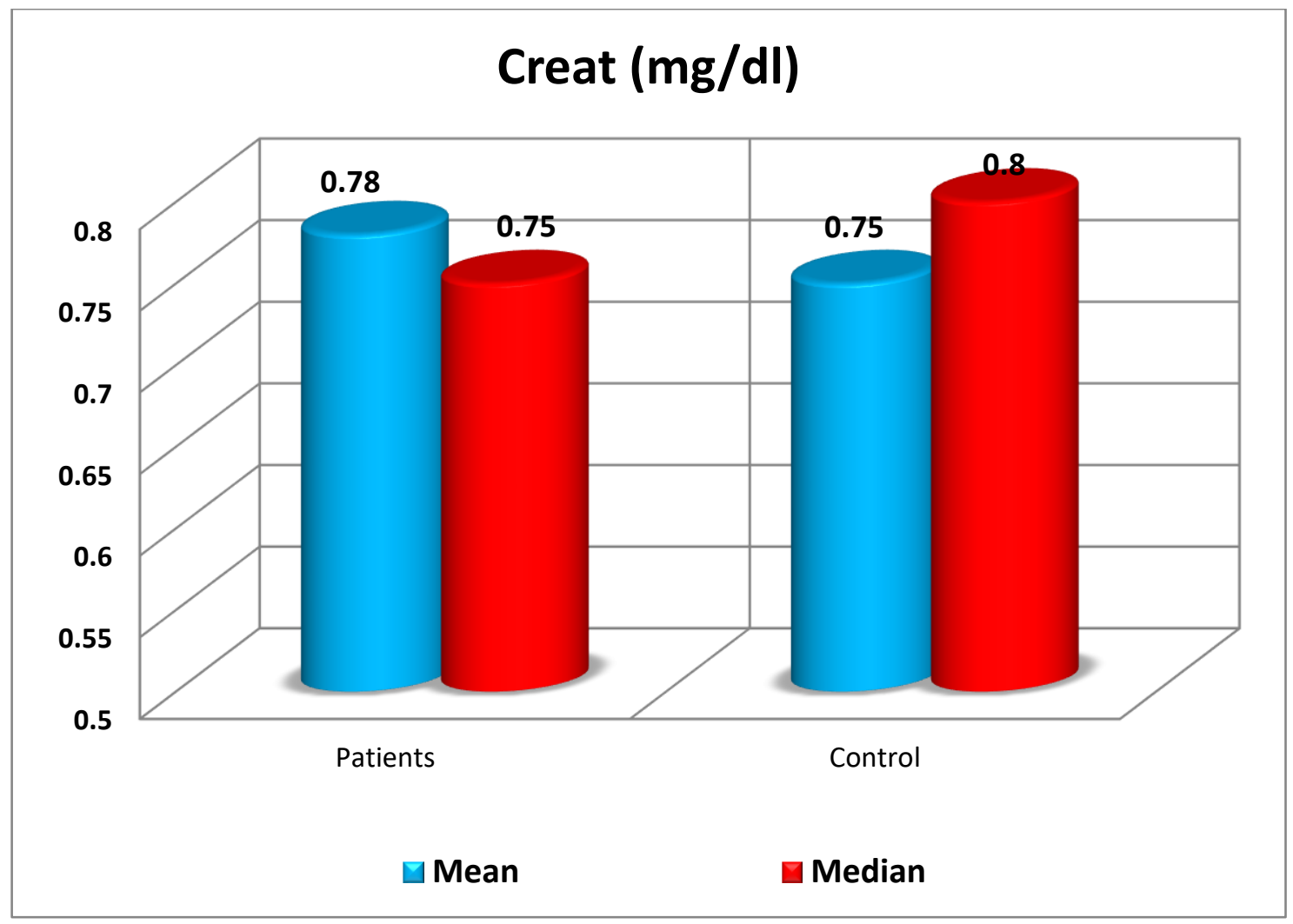

Figure (12): Comparison between studied groups as regard serum Create. 


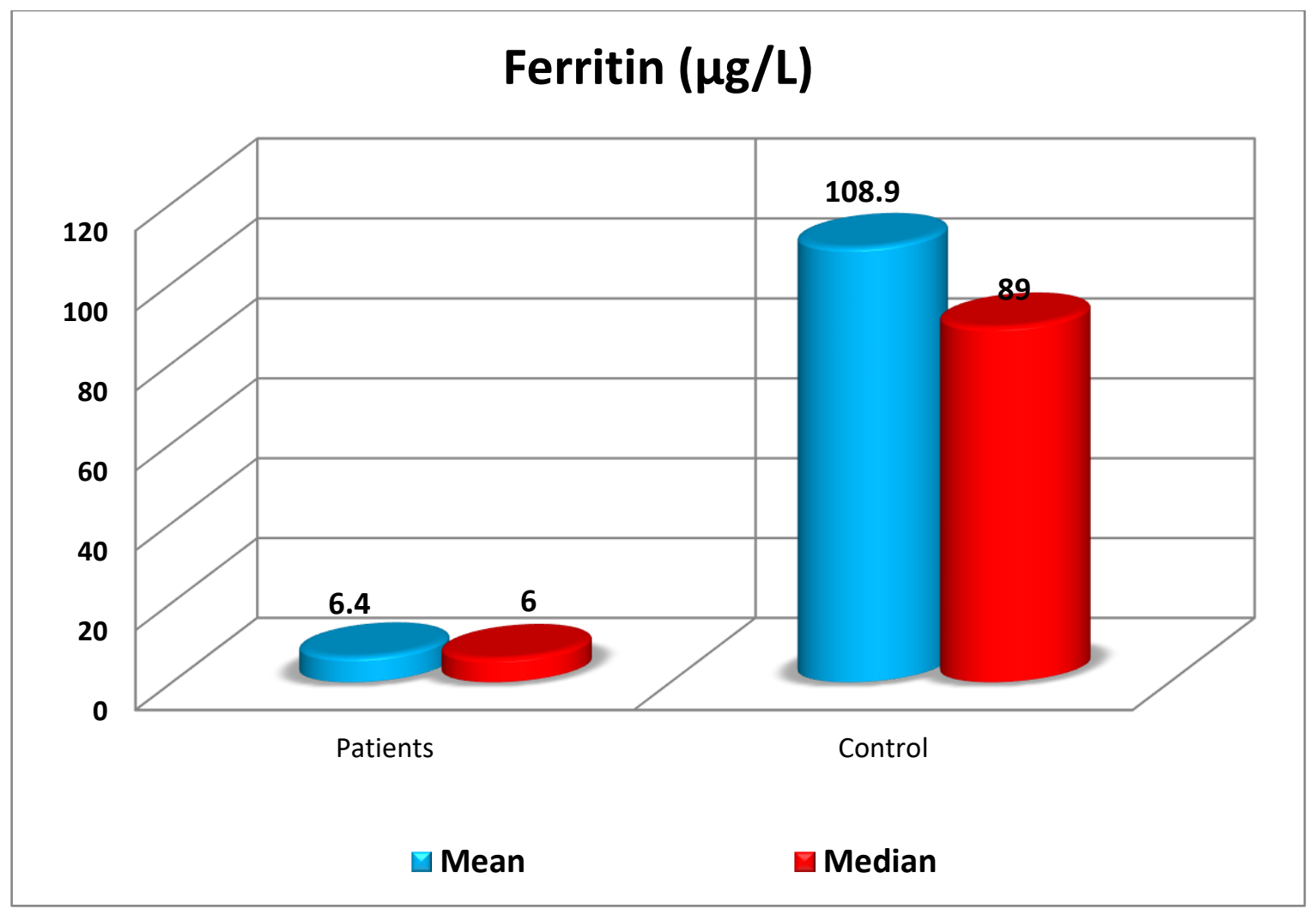

Figure (13): Comparison between studied groups as regard serum ferritin.

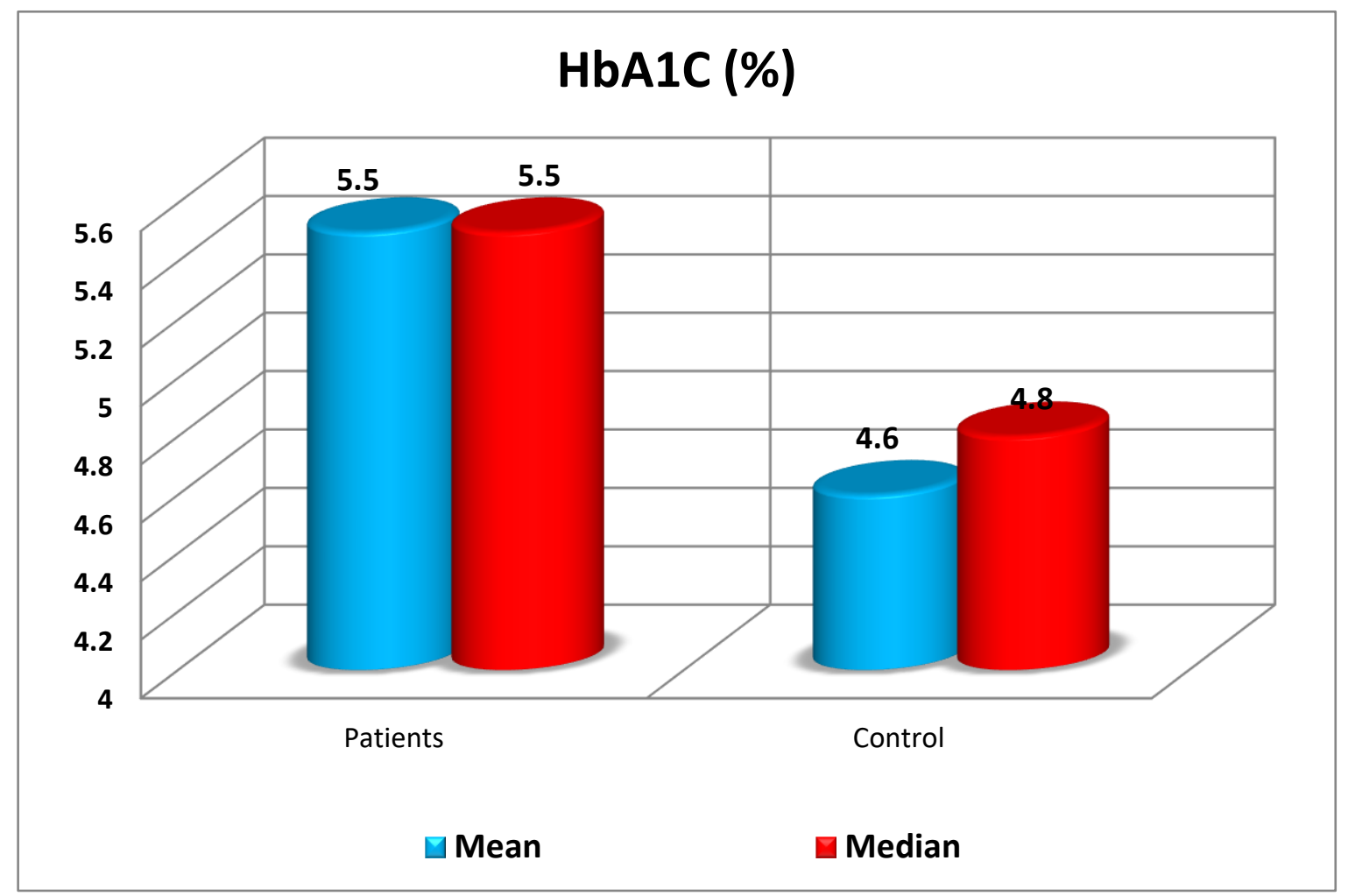

Figure (14): Comparison between studied groups as regard HbA1C. 
Table (2): Correlation study between HbA1C and other studied parameters in patients' group.

\begin{tabular}{|c|c|c|c|c|c|}
\hline \multicolumn{6}{|l|}{ Patients group } \\
\hline Variables & $(\mathbf{r})$ & p-value & Variables & $(\mathbf{r})$ & p-value \\
\hline HbA1C vs age & 0.27 & $0.082 \mathrm{NS}$ & HbA1C vs RDW & 0.17 & $0.294 \mathrm{NS}$ \\
\hline HbA1C vs WBCs & 0.23 & $0.161 \mathrm{NS}$ & HbA1C vs PLT & 0.24 & $0.134 \mathrm{NS}$ \\
\hline HbA1C vs Hb & -0.37 & $0.019 S$ & HbA1C vs FBS & 0.03 & $0.856 \mathrm{NS}$ \\
\hline HbA1C vs MCV & -0.39 & $0.013 \mathrm{~S}$ & HbA1C vs Creat & 0.1 & $0.533 \mathrm{NS}$ \\
\hline HbA1C vs MCH & -0.45 & $0.003 \mathrm{~S}$ & HbA1C vs Urea & 0.24 & $0.132 \mathrm{NS}$ \\
\hline HbA1C vs HCT & 0.09 & $0.598 \mathrm{NS}$ & HbA1C vs Ferritin & -0.33 & $0.035 S$ \\
\hline
\end{tabular}

(r): Pearson correlation coefficient.

S: p-value $<0.05$ is considered significant.

NS: p-value $>0.05$ is considered non-significant.

- $\quad$ Statistically significant (p-value $<\mathbf{0 . 0 5})$ :

$\bigcirc$ Negative correlation ( $\mathbf{r}=\mathbf{- \mathbf { 0 . 3 7 }}$ ) between $\mathrm{HbA1C}$ and $\mathrm{Hb}$ in patients' group.

$\bigcirc$ Negative correlation ( $\mathbf{r}=\mathbf{- 0 . 3 9})$ between HbA1C and MCV in patients' group.

$\circ$ Negative correlation $(\mathbf{r}=\mathbf{- \mathbf { 0 . 4 5 }})$ between $\mathrm{HbA1C}$ and $\mathrm{MCH}$ in patients' group.

$\circ$ Negative correlation $(\mathbf{r}=\mathbf{- 0 . 3 3})$ between HbA1C and Ferritin in patients' group.

- No statistically significant (p-value > 0.05) correlation between HbA1C and other studied parameters in patients' group. 


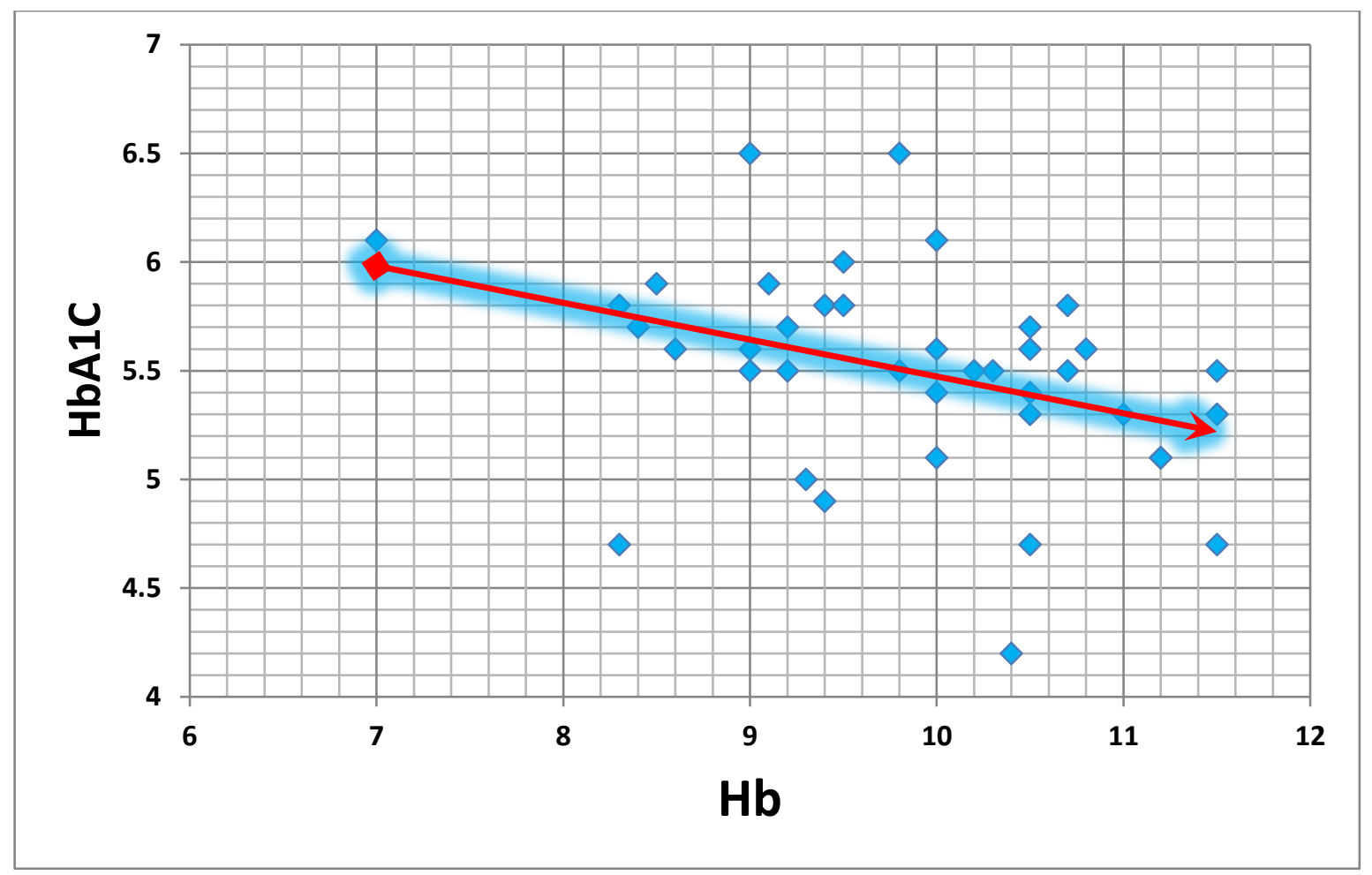

Figure (15): Negative correlation between $\mathrm{HbA1C}$ and $\mathrm{Hb}$ in patients' group.

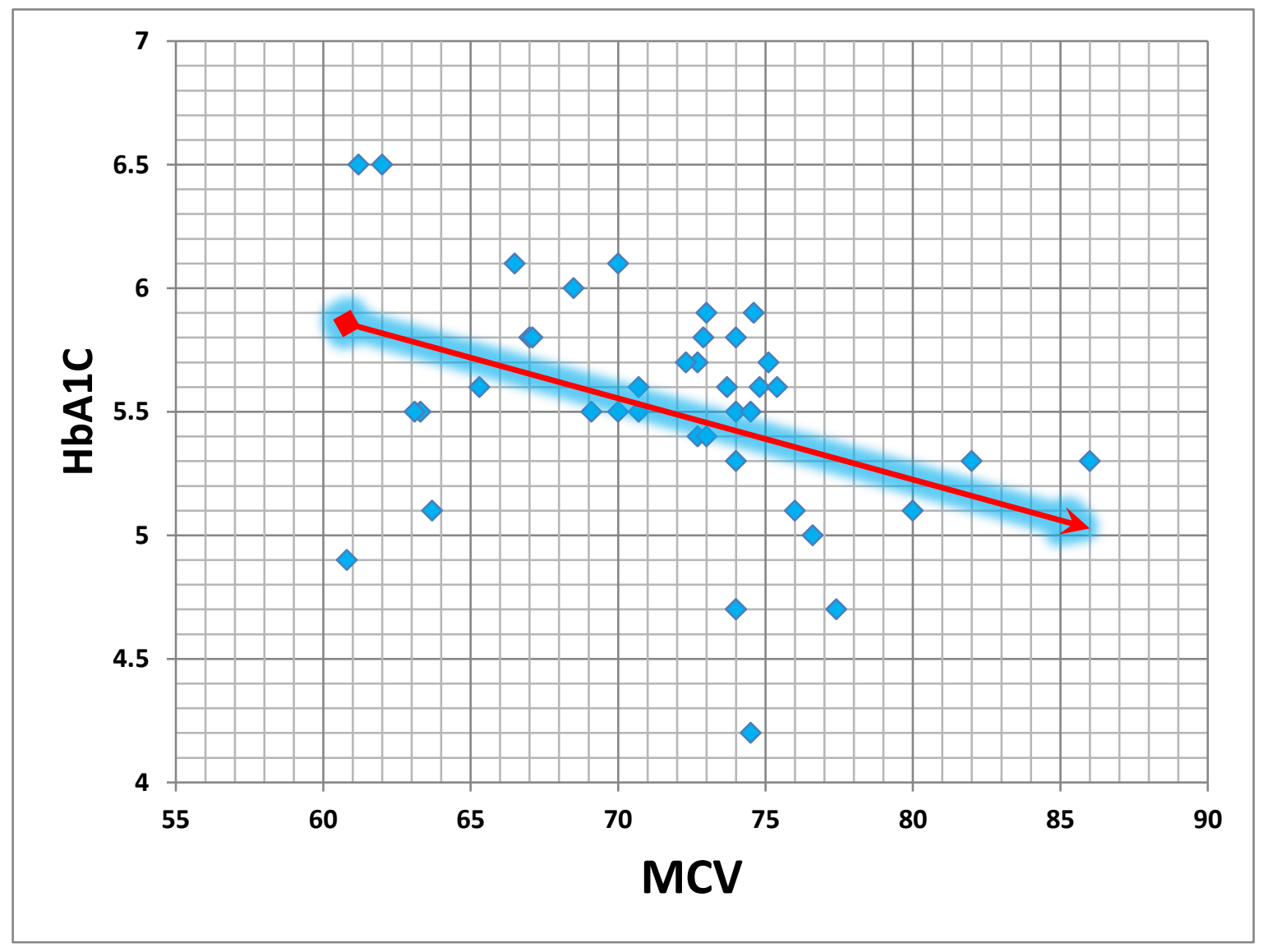

Figure (16): Negative correlation between $\mathrm{HbA1C}$ and MCV in patients' group. 


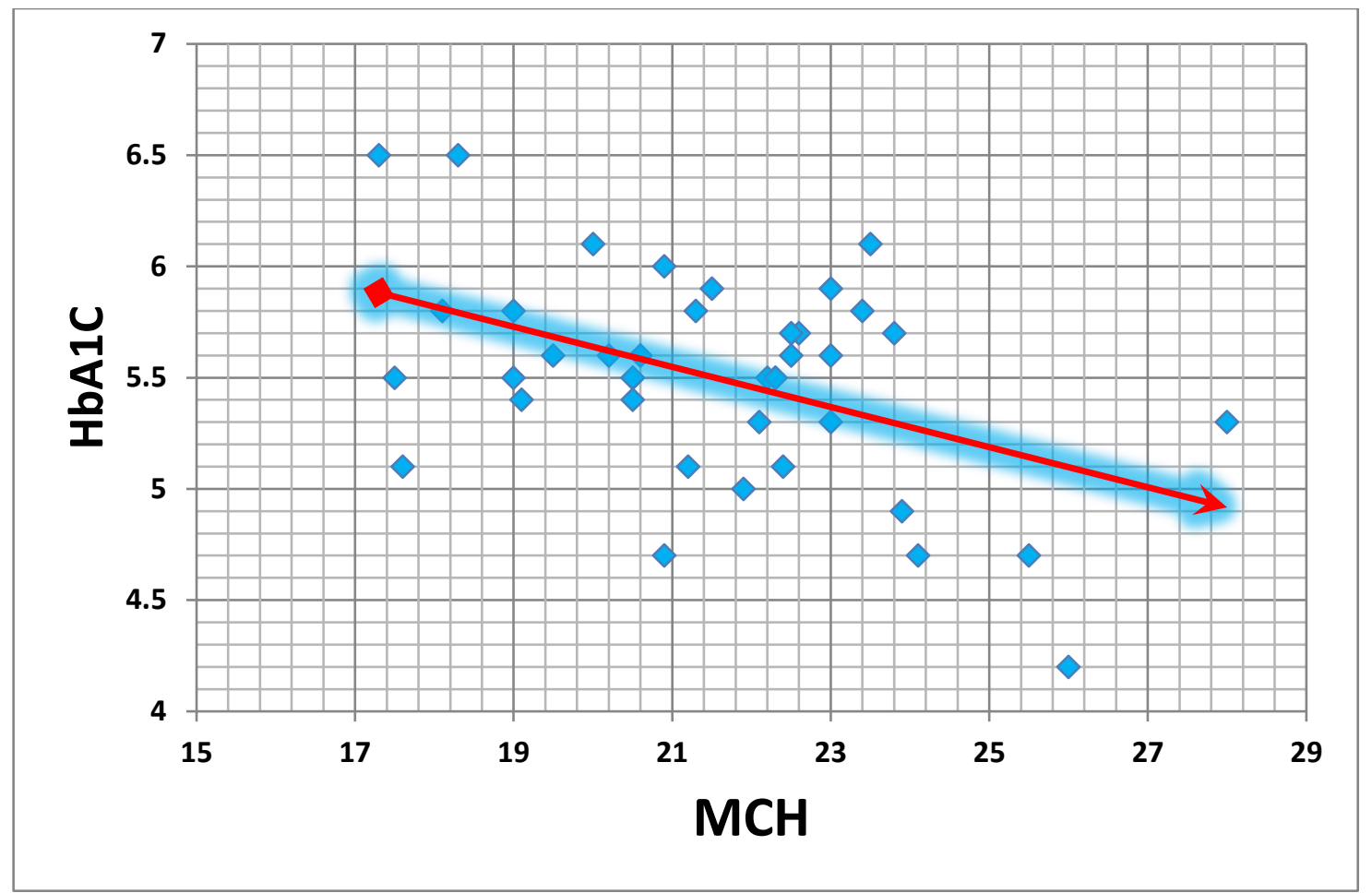

Figure (17): Negative correlation between $\mathrm{HbA1C}$ and $\mathrm{MCH}$ in patients' group.

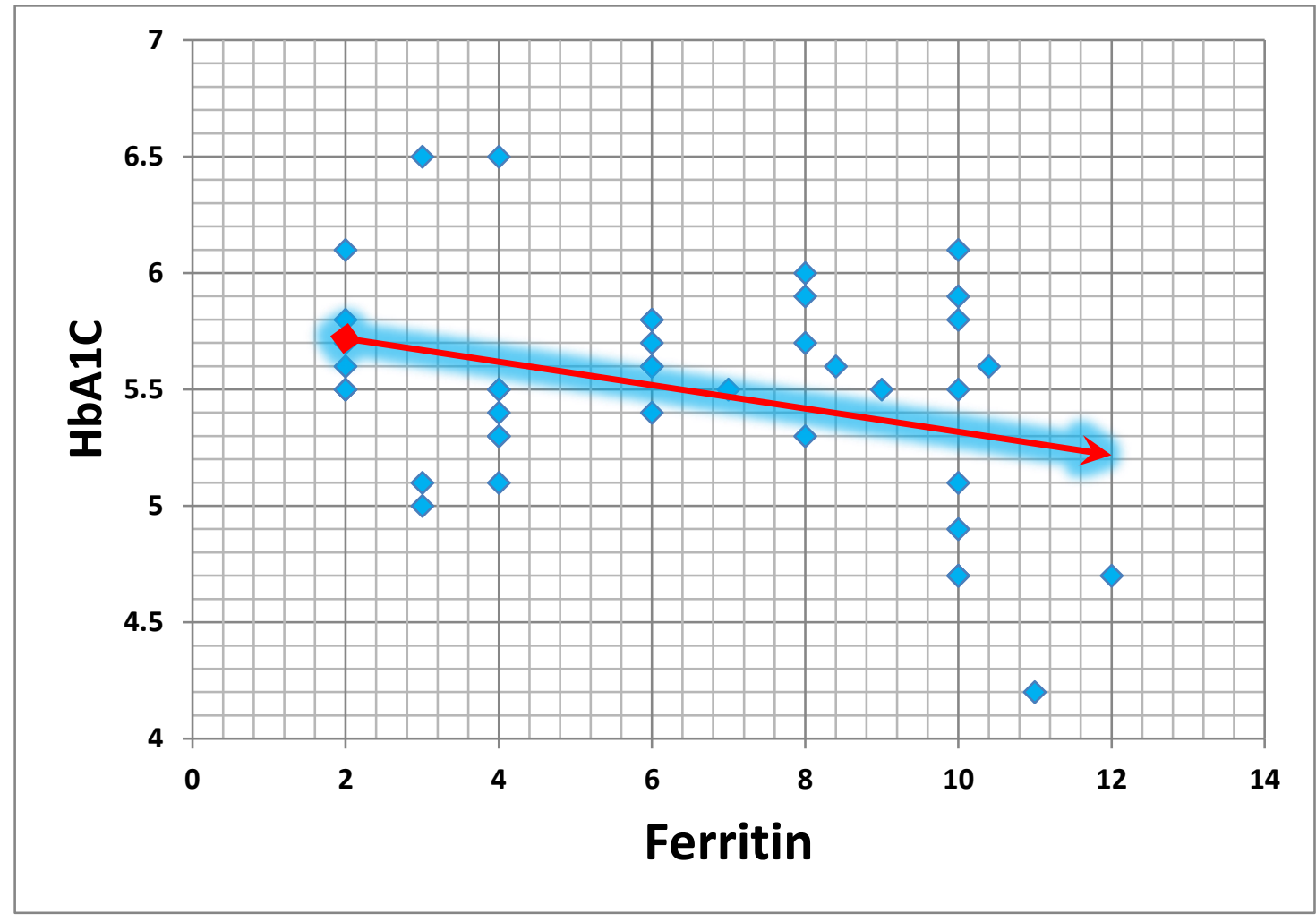

Figure (18): Negative correlation between HbA1C and Ferritin in patients' group. 
Table (3): Correlation study between ferritin and other studied parameters in patients' group.

\begin{tabular}{|c|c|c|c|c|c|}
\hline \multicolumn{6}{|l|}{ Patients group } \\
\hline Variables & (r) & p-value & Variables & (r) & p-value \\
\hline Ferritin vs age & -0.11 & $0.488 \mathrm{NS}$ & Ferritin vs RDW & -0.10 & $0.552 \mathrm{NS}$ \\
\hline Ferritin vs WBCs & -0.06 & $0.711 \mathrm{NS}$ & Ferritin vs PLT & -0.12 & $0.458 \mathrm{NS}$ \\
\hline Ferritin vs $\mathbf{H b}$ & 0.18 & $0.266 \mathrm{NS}$ & Ferritin vs FBS & 0.24 & $0.135 \mathrm{NS}$ \\
\hline Ferritin vs MCV & 0.10 & $0.524 \mathrm{NS}$ & Ferritin vs Creat & -0.03 & $0.866 \mathrm{NS}$ \\
\hline Ferritin vs MCH & 0.21 & $0.193 \mathrm{NS}$ & Ferritin vs Urea & -0.05 & $0.755 \mathrm{NS}$ \\
\hline Ferritin vs HCT & 0.21 & $0.185 \mathrm{NS}$ & Ferritin vs HbA1C & -0.24 & $0.129 \mathrm{NS}$ \\
\hline
\end{tabular}

(r): Pearson correlation coefficient. significant.

No statistically significant ( $\mathrm{p}$-value $>0.05$ ) correlation between ferritin and other studied parameters in patients' group.

\section{Discussion:}

Iron deficiency anemia is one of the most common types of anemia. HbA1c is a glycated $\mathrm{Hb}$ that is used to determine the glycemic status of a patient for the past 3 months. But there are a few conditions which also affect the levels of HbA1c like hemolytic anemias, acute blood loss, ID, alcoholism, pregnancy, chronic kidney disease and hemoglobinopathies [8].

Our results showed no significant difference between studied groups as regard age (the mean age in patients' group was $32.4 \pm 9.9$ years while it was $28.7 \pm 5.4$ years in control group in agreement with [3] who studied 126 IDA patients, the youngest patient was 15 years old and the oldest was 82 years and reported that IDA was more common in the age group of 3140 years.

Also, [8] who studied 1000 IDA patients aged between 18-70 years and reported that
NS: $p$-value $>0.05$ is considered non-

the mean age for the patient group was 32.7 \pm 1.8 while that of control group was 33.2 \pm 1.4 .

Our results showed that IDA is more common among females than males in agreement with [3] who studied 63 IDA patients, and reported that 47 were females constituting about $75 \%$ and 16 were males constituting about $25 \%$

Also, [8] who studied 1000 IDA patients, and reported that $68 \%$ were females and $32 \%$ were males.

Our results showed decrease in $\mathrm{Hb}$, RBCs indices (MCV and $\mathrm{MCH}$ ), HCT, and ferritin in IDA patients than control group in agreement with several studies such as [9] who investigated $\mathrm{HbA} 1 \mathrm{c}$ values in IDA patients, found that there were differences in the mean levels of hematological parameters and ferritin between subjects affected by IDA and controls $(\mathrm{P}<0.0001)$, and reported that $\mathrm{Hb}, \mathrm{HCT}, \mathrm{MCV}, \mathrm{MCH}$, and ferritin values were lower in ID subjects. 
Also, [3] who investigated HbA1c of 63 IDA non-diabetic patients. $\mathrm{Hb}$, and ferritin levels were low among the patient group and the peripheral blood smear showed microcytic hypochromic picture while $\mathrm{Hb}$ and ferritin levels were normal in healthy group $(\mathrm{P}>0.05)$.

In contrast to these studies, [10] who investigated IDA patients to study the prevalence of IDA and reported that $45.1 \%$ were microcytic and others were normocytic.

Our results showed increase in RDW in IDA patients than control group in agreement with [11] who investigated patient with IDA to differentiate between causes of microcytic anemia and reported that patient with IDA had high results of RDW (17.9\%).

In contrast with [12] who studied normal RDW with IDA depending on how long the anemia has persisted, patients who have severe IDA for months to years are expected to have a normal rather than a high RDW, as their RBCs of normal size have all been replaced by microcytes.

Our results showed increase in PLT in IDA patients than control group in agreement with [13] who investigated PLT of 308 IDA patient to study the effect of iron therapy on PLT count and reported that Patients with IDA had thrombocytosis because of increased erythropoietin (EPO) that were significantly decreased after treatment of IDA.

Our results showed no significant difference between studied groups as regard FBS in agreement with [14] who studied the effect of IDA on HbA1c level in non-diabetic individuals, investigated FBG of all subjects, and reported that there were no differences in the levels of FBG between the IDA and the control groups [P>0.05].
Our results showed no significant difference between studied groups as regard KFTs in agreement with [15] who studied the effect of IDA on HbA1c level, investigated blood urea of all subjects and reported that there was no significant difference between studied groups as regarding blood urea.

Our results showed that patients with IDA had higher HbA1c levels when compared with control group in agreement with results obtained in different studies such as [16] who studied the effect of IDA on HbA1c level in Asians and Indians before and after treatment, and reported that significant higher $\mathrm{HbA1c}$ levels were observed in IDA subjects $(5.51 \pm 0.696 \%)$ compared to healthy controls (4.85 \pm $0.461 \%) \quad(p<0.001)$, most of them decreased after iron therapy. This study suggested that ID leads to prolongation of erythrocyte survival and may alters the quaternary structure of $\mathrm{Hb}$ leading to elevated level of $\mathrm{HbA} 1 \mathrm{c}$.

Choudhary [17] who investigated HbA1c of 50 IDA patient cases and 50 healthy controls to study the effect of IDA on HbA1c in non-diabetic Adults. This study showed that the HbA1C was significantly higher in the ID patients $(5.88 \pm 0.41 \%)$ as compared to the controls $(5.03 \pm 0.17 \%)$ respectively $(\mathrm{P}<.05)$ and reported that the quaternary structure of the $\mathrm{Hb}$ molecule may be altered, and that the glycation of the $\beta$-globin chains occurs more readily.

Intra [9] who studied HbA1c values in IDA patients, showed that the mean values of HbA1c were significantly higher in anemic subjects $(5.59 \%)$ than those measured in individuals without anemia (5.34\%) $(\mathrm{P}<0.0001)$, and reported that a state of ID affects the life span of RBCS and the erythrocyte is decreased, leading to an older population of RBCs that are in contact with plasma glucose longer causing falsely higher HbA1c measurements, and in patients affected by IDA, levels of MDA 
is significantly higher compared to healthy individuals. In vitro, $\mathrm{HbA} 1 \mathrm{c}$ levels increase when erythrocytes are incubated with MDA, in vivo studies have not yet been performed to confirm this biological process.

In Amreen [7] study it was found that patients with IDA had higher HbA1c levels, and it was reported that there is a relationship between iron metabolism and glucose homeostasis, higher iron level modulate the action and secretion of insulin, thus lower the iron level higher in the glycation of HbAlc leading to false high values in diabetic as well as nondiabetic individuals.

In Rajagopal [18] study a total of 150 nondiabetics aged $>18$ years (75 patients with IDA and 75 patients without IDA) were included in this study. In this study the non-diabetics with IDA had a mean HbA1C $(6.84 \pm 0.07 \%)$ which was significantly higher than the non-anemic group $(5.12 \pm 0.04 \%)(\mathrm{p}<0.05)$. The proposed theories for increased $\mathrm{HbA} 1 \mathrm{C}$ levels in IDA were:

Alteration of quaternary structure of $\mathrm{Hb}$ leading to more rapid glycation of globin chain.

Decrease in the $\mathrm{Hb}$ concentration might lead to an increase in the glycated fraction at a constant glucose level, because HbA1C is measured as a percentage of total $\mathrm{HbA}$. In IDA, reduced RBCs production leads to a higher average age of circulating erythrocytes and therefore, increased HbA1C levels.

Moulani [14] who studied 50 IDA patients of the mean age (37.44 \pm 5.11 years) among which 12 were males and 38 were females and 50 age matched healthy subjects, and reported that the mean $\mathrm{HbAlc}$ in the patients with IDA $(9.10 \pm 1.08 \%)$ was higher than that in the control non anemic group $(5.21 \pm 0.45 \%) \quad(\mathrm{P}<0.001)$. The mechanism of increased level of $\mathrm{HbA1c}$ was not clear in this study.
In Parlapally [3] study a total of 126 nondiabetics subjects (63 patients with IDA and 63 patients without IDA as a control) were enrolled in this study, investigated $\mathrm{HbA} 1 \mathrm{c}$ of all subjects, and reported that the mean HbA1c level was higher in the IDA group $(6.13 \pm 0.57 \%)$ than healthy group $(5.12 \pm 0.30 \%) \quad(\mathrm{P}<0.001)$. This study suggested that in ID, the quaternary structure of the $\mathrm{Hb}$ molecule was alterd and the glycation of globin chain occurred more in the absence of iron.

In contrast to these studies, Solomon [6] who studied the effect of IDA on HbA1c in diabetic patients and reported that $\mathrm{HbA} 1 \mathrm{c}$ level was significantly lower in IDA group $(6.18 \pm 1.57 \%)$ compared with the nonIDA diabetic patients $(7.74 \pm 1.81 \%)$ $(p<0.05)$. This study suggested that the reason for lower $\mathrm{HbA1c}$ was due to the severity of anemia in the study participant.

Silva [15] who reported that mild anemia did not show significant effects on HbA1c results.

Altuntas [19] who studied 263 subjects (the patient group consisted of 131 patients with IDA and the control group consist of 132 healthy individuals), and reported that the mean $\mathrm{HbA} 1 \mathrm{c}$ level was significantly lower in the group with IDA $(5.4 \%)$ than in the healthy control group (5.9\%) $(p<0.05)$. The mechanism of decreased level of HbA1c was not clear in this study and illustrated that the different results by different studied resulting of different analytical methods were used.

Hussain [4] who found that the mean baseline level of HbA1c in IDA patients was lower than healthy individuals, and suggested that the HbA1c value difference noted in different studies have been appeared because of post translational modification of $\mathrm{Hb}$ rather than glycosylation in IDA, the modified $\mathrm{Hb}$ elute with $\mathrm{HbA}$ and affect reading in ion 
exchange chromatography assay methods, however this modification does not affect affinity gel assays because this technique depends on the binding between the gel and glucose residues on the globin chain alone.

Our results showed negative correlation between $\mathrm{HbA1C}$ with $\mathrm{Hb}$, ferritin, MCV and $\mathrm{MCH}$ in patients' group in agreement with several studies such as Rajagopal [18] who analyzed $\mathrm{HbA} 1 \mathrm{C}$ results in different degrees of IDA anemia and reported that HbA1C level increased as severity of anemia worsen.

Madhu [16] who observed that significant negative correlation between $\mathrm{HbA} 1 \mathrm{c}$ with $\mathrm{Hb}, \mathrm{MCH}$, and serum ferritin in IDA subjects, and these parameters increased after oral iron supplementation.

Silva [15] who classified the IDA patients according to degree of anemia, observed

\section{References}

1. Syrjala, Al-alimi AA, Bashanfer S, and Morish MA (2018): Prevalence of Iron Deficiency Anemia among University Students in Hodeida Province, Yemen. Anemia; 2018:17.

2. Camaschella C (2015): IronDeficiency Anemia. New England Journal of Medicine; 372(19): 1832-1843.

3. Rajpurkar, Parlapally RP, Sukumar KR, and Srujana T (2016): Effect of iron deficiency anemia on glycation of hemoglobin in non-diabetics. The Journal of the Association of Physicians of India; 4(5):192-196.

4. Hussain N (2015): Haemoglobin A1c and Iron Deficiency Anaemia our Understanding Through the Decades. Romanian Journal of that $\mathrm{HbA} 1 \mathrm{c}$ results were higher in patients with moderate and severe anemia, however mild anemia did not show significant effects on $\mathrm{HbA} 1 \mathrm{c}$ results, and reported that there were significant negative correlations between $\mathrm{Hb}$ and ferritin, $\mathrm{MCV}$ and $\mathrm{MCH}$ with HbA1c $(\mathrm{p}<0.01)$.

In contrast to these studies, Solomon [6] who reported that there was no correlation between $\mathrm{HbA} 1 \mathrm{C}$ with $\mathrm{MCV}$ and $\mathrm{MCH}$ in IDA diabetic patients.

Also, Chowdeswari [8] who investigated that mean $\mathrm{HbAlc}$ value was $6.14 \pm 1.1 \%$ among the moderate anemia cases while it was $5.5 \pm 1.3 \%$ among the severe anemia patients and reported that there was positive correlation between $\mathrm{HbAlc}$ and $\mathrm{Hb}$.

Diabetes Nutrition and Metabolic Diseases; 22(3): 289-296.

5. Sherwani SI, Khan HA, Ekhzaimy A, Masood A, and Sakharkar MK (2016): Significance of HbA1c Test in Diagnosis and Prognosis of Diabetic Patients. Biomarker Insights; 11: 95-104.

6. Solomon A, Hussein M, Negash M, Ahmed A, Bekele F, and Kahase D (2019): Effect of iron deficiency anemia on HbA1c in diabetic patients at Tikur Anbessa specialized teaching hospital, Addis Ababa Ethiopia. BMC Hematology.; 19 (1): 2

7. Amreen N, and Ghulam NB (2018): Influence of Iron Deficiency Anemia on HbA1c: A Review. Curre Res Diabetes \& Obes J.; 5(3): 555665. 
8. Chowdeswari N, Jaya $\mathrm{N}$ and Rama Rao BV (2016): Incidence and Association of Glycated Hemoglobin Levels with Iron Deficiency Anemia in Patients with or without Diabetes - A Study in a Semi Urban Area. International Journal of Clinical Biochemistry and Research; 3 (1): 124-128.

9. Intra J, Limonta G, Cappellini F, Bertona M, and Brambilla P (2019): Glycosylated Hemoglobin in Subjects Affected by IronDeficiency Anemia. Diabetes \& Metabolism Journal; 43(4): 539.

10. Lee JO, Lee JH, Ahn S, Kim JW, Chang H, Kim YJ, and Lee JS (2014): Prevalence and Risk Factors for Iron Deficiency Anemia in the Korean Population: Results of the Fifth Korea National Health and Nutrition Examination Survey. Journal of Korean Medical Science; 29(2): 224.

11. Patol JB (2015): RDW as differential parameter between microcytic anemias in "pure" and concomitant forms. Jornal Brasileiro de Patologia e Medicina Laboratorial; 51(1): 1676-2444.

12. Jori E, Marisa BM, Vishnu VB, Reddy, and Gangaraju R (2019): Three neglected numbers in the CBC: The RDW, MPV, and NRBC count. Cleveland Clinic Journal of Medicine; 86 (3): 167-172.

13. Ayan NN, Savaş Z, Bireroğlu N, Keleş A, Aksoy, NN, and Serin O (2015): Effect of Iron Therapy on Platelet Counts. JAREM.; 5: 94-96.

14. Moulani MR and Gawali PS (2017): Effect of Iron deficiency on glycation of hemoglobin in nondiabetics. Annals of Clinical Chemistry and Laboratory Medicine; 2(2): 4-7.

15. Silva JF, Pimentel AL, and Camargo JL (2016): Effect of iron deficiency anaemia on $\mathrm{HbA1c}$ levels is dependent on the degree of anaemia. Clin Biochem.; 49:117-20.

16. Madhu SV, Raj A, Gupta S, Giri S, and Rusia U (2017): Effect of iron deficiency anemia and iron supplementation on HbA1c LevelsImplications for diagnosis of prediabetes and diabetes mellitus in Asian Indians. Clin Chim Acta.; 468: 225-229.

17. Choudhary DS, Choudhary DSD, Choudhary DH, and Gandhi DR (2019): The effect of iron deficiency anemia on glycated hemoglobin (hbalc) in non-diabetic adults. International Journal of Medical and Biomedical Studies; 3(8): 140-142.

18. Rajagopal L, Ganapathy S, Arunachalam S, Raja V, and Ramraj B (2017): Does Iron Deficiency Anaemia and its Severity Influence HbA1C Level in Non Diabetics? An Analysis of 150 Cases. J Clin Diagn Res.;11(2):13-15.

19. Altuntas SÇ, Evran M ,Gürkan E, Sert M,and Tetiker T (2020): HbA1c level decreases in iron deficiency anemia. Wiener klinische Wochenschrift; 132(78):1. 